J. Dairy Sci. 99:5965-5965

http://dx.doi.org/10.3168/jds.2016-99-7-5965

(c) American Dairy Science Association ${ }^{\circledR}, 2016$.

\title{
Corrigendum to "Short communication: Altered expression of specificity protein 1 impairs milk fat synthesis in goat mammary epithelial cells" (J. Dairy Sci. 99:4893-4898)
}

\section{J. J. Zhu, J. Luo, H. F. Xu, H. Wang, and J. J. Loor}

Affiliations for authors J. Luo. H. F. Xu, and H. Wang (page 4893) were incorrectly identified. J. Luo. H. F. Xu, and H. Wang are affiliated with Shaanxi Key Laboratory of Molecular Biology for Agriculture, College of Animal Science and Technology, Northwest A\&F University, Yangling, Shaanxi, 712100, P. R. China

The authors regret the error.

\section{REFERENCES}

Zhu, J. J., J. Luo, H. F. Xu, H. Wang, and J. J. Loor. 2016. Short communication: Altered expression of specificity protein 1 impairs milk fat synthesis in goat mammary epithelial cells. J. Dairy Sci. 99(6):4893-4898. 